\title{
ORIGINALS
}

\section{Zagreb Diabetes Survey}

\author{
ŽELIMIR JAKŠIĆ
}

Andrija Stampar School of Public Health, Medical Faculty, University of Zagreb and

\section{Zdenko SKRabalo}

\author{
Department of Medicine, within the Ozren Novosel Hospital, Vuk Vrhovac Centre for Diabetes, Medical Faculty \\ University of Zagreb
}

Received: January 29, 1969

Summary. The results are presented of a diabetic survey in Zagreb where, in a typical population sample from five General Practice Units, $88.9 \%$ of the total number of inhabitants aged over $15(9176)$ were examined. The examination in the screening phase comprised the deter. mination of blood sugar $1-2 \mathrm{~h}$ after the largest daily meal. - The results are analysed from technical, sociomedical, and epidemiological aspects. 1. For standardized epidemiological comparisons, blood sugar measurements after glucose loading should be adapted and so arranged that the validity of the screening phase may be assessed. 2. All blood sugar distributions proved unimodal, continuous, and positively skewed. Consequently, all critical diagnostic values are necessarily arbitrary and of greater importance to group than individual diagnosis. The OGTT results in so-called borderline cases proved unreliable in the course of time. Classifications based upon single determinations are inadequate. 3 . In the epidemiological studies of diabetes, a quantitative approach to the analysis of relationship between the continuously varying blood sugar level and other epidemiological characteristics of the population, has been neglected. The use of this approach in the Zagreb Diabetes Survey promises further refinements in the understanding of the importance of glucose tolerance in complete populations.

\section{Enquête sur le diabète à Zagreb}

Résumé. Les auteurs présentent les résultats d'une enquête sur le diabète à Zagreb, où, dans un échantillon représentatif de population provenant de cinq unités de médecine générale, on a examiné $88.9 \%$ du nombre total d'habitants âgés de plus de 15 ans (9176). Dans la phase de dépistage, l'examen comportait la détermination de la glycémie $1-2 \mathrm{~h}$ après le repas le plus important de la journée. Les résultats sont analysés des points de vue technique, socio-médical et épidémiologique. 1. Pour établir des comparaisons épidémiologiques standardisées, les mesures de la glycémie après charge en glucose doivent être adaptées et arrangées de telle sorte que la validité de la phase de dépistage puisse être évaluée. 2. Toutes les distributions de glycémie se sont avérées unimodales, continues et tout à fait dissymétriques. Par conséquent, toutes les valeurs diagnostiques critiques sont nécessairement arbitraires et d'une plus grande importance pour les diagnostics de groupe que pour les diagnostics individuels. Les résultats des tests de tolérance au glucose oral dans les cas limites se sont montrés incertains au cours du temps. Les classifications basées sur des déterminations uniques sont inadéquates. 3. Dans les études épidémiologiques sur le diabète, on a négligé de faire une approche quantitative de l'analyse de la relation existant entre la variation continue du taux glycémique et les autres caractéristiques épidémiologiques de la population. L'utilisation de cette approche dans l'enquête sur le diabète à Zagreb promet d'autres perfectionnements dans la compréhension de l'importance de la tolérance au glu. cose dans des populations entières.

\section{Diabetes-Reihenuntersuchung in Zagreb}

Zusammenfassung. Es werden die Ergebnisse einer Reihenuntersuchung auf Diabetes in Zagreb dargestellt, wo $88.9 \%$ der Einwohner über 15 Jahre (9176), die in 5 Zentralen für Allgemeinpraxis behandelt wurden, zur Untersuchung kamen. In der Screeningphase wurde dabei der Blutzucker $1-2 \mathrm{~h}$ nach der größten Tagesmahlzeit bestimmt. Die Ergebnisse werden unter technischen, sozialmedizinischen und epidemiologischen Gesichtspunkten analysiert. 1. Für standardisierte epidemiologische Vergleiche sollten die Blutzuckermessungen nach Glucosebelastung so modifiziert werden, daß die Aussagekraft der Screeningphase sich abschätzen läßt. 2. Alle Blutzuckerverteilungskurven erwiesen sich als eingipflig, stetig und zeigten eine positive Schiefe. Es folgt daraus, daß alle kritischen diagnostischen Werte eine erhebliche Zufallskomponente erhalten und mehr für die Diagnose von Gruppen als von Individuen geeignet sind. Die Resultate der oralen Glucosebelastung in sogenannten Grenzfällen stellten sich bei Verlaufskontrollen als unzuverlässig heraus. Eine Einzelbestimmung reicht für eine Klassifikation nicht aus. 3. Bei epidemiologischen Diabetesstudien ist bisher der Versuch einer quantitativen Analyse der Beziehungen zwischen den ständig schwankenden Blutzukkerspiegeln und anderen epidemiologischen Eigenschaften der untersuchten Bevölkerungsgruppe vernachlässigt worden. Die Anwendung derartiger Methoden auf die Diabetesstudie in Zagreb verspricht weitere Verbesserungen im Verständnis der Bedeutung der Glucosetoleranz bei geschlossenen Bevölkerungsgruppen.

Key-words: Diabetes Survey, technical, sociomedical, epidemiological aspects of results.

\section{Introduction}

The Zagreb Diabetes Survey was designed as a part of an integral clinical, epidemiological and social approach to the health protection of diabetics in the re- gion. It was planned to answer several questions from different aspects:

1. What is the validity of diabetes screening procedures in large population surveys? 
2. To what extent can a survey of such a type help the as yet undiscovered diabetics and borderline cases?

3 . Is the pattern of epidemiology of diabetes in the Zagreb region different from common experience in Europe and North America?

The screening phase of the survey was completed in 1963 and 1964. This was the first diabetes survey in an open but defined population in Yugoslavia.

\section{Organization of the survey}

The Zagreb Diabetes Survey has been designed to evolve as a five-phase project: the preparatory phase, the screening phase $(1-2 \mathrm{~h}$ postprandial sugar analysis in the capillary blood and in urine), the diagnostic phase based upon the use of the $100 \mathrm{~g}$ oral glucose tolerance test (OGTT) according to the pattern proposed by Schulack [14], the clinical phase coupled

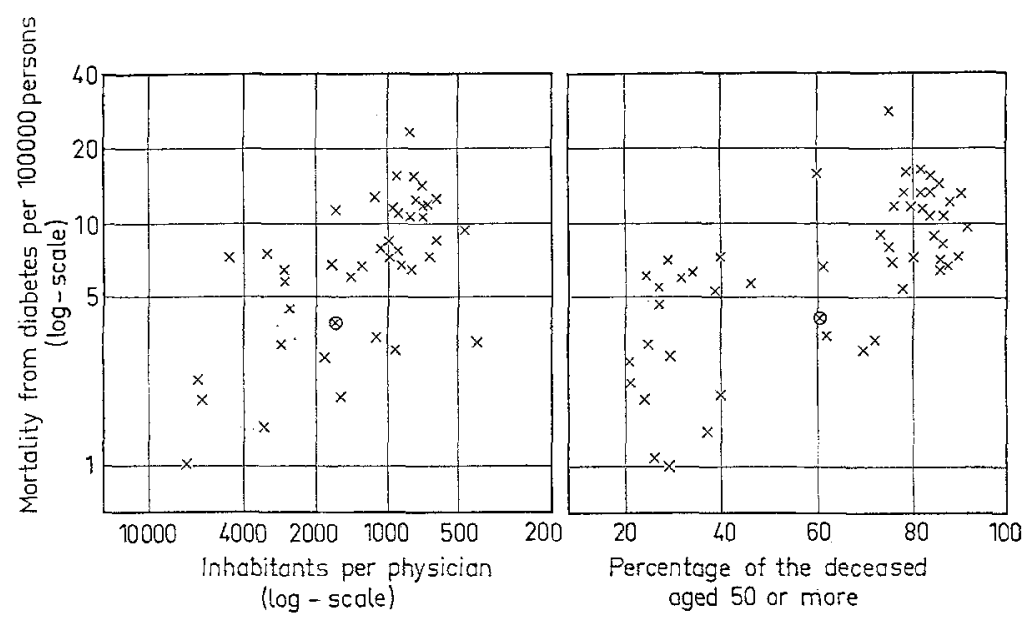

Fig. 1. Mortality from diabetes in some countries in 1959 (WHO: Annual epid. and vital statistics) Yugoslavia $\otimes$

\section{Selection of population}

At that time, judged according to the number of inhabitants per physician and the number of deaths in the over-50-years age group, Yugoslavia was somewhere halfway between developed and developing countries [1]. Mortality from diabetes could have been expected to be higher than was actually recorded. [6] (Fig. 1)

Within Yugoslavia, in Croatia, there have been great variations in the average mortality from diabetes, mostly connected with the development of health services and also with the age structure of the population [6, 7]. (Fig. 2)

In view of this situation, it was decided to carry out the survey in the territory with the best developed health service, and to try to follow up the occurrence of diabetes, on the basis of a typical sample, in the course of the rapid urbanization underway in the $\mathrm{Za}$ greb region. Five out of 269 General Practice Units were selected: one in the town centre, two in the periphery, and one each in the outskirts and the rural area.

In these geographically well-defined territories, there were about 12000 inhabitants. The sample covered only residents over 15 years old (97176). The response rate was $88.9 \%$ (8161). Of the persons not responding, $419(4.6 \%)$ were not available, $387(4.2 \%)$ refused, and $209(2.3 \%)$ were not examined for other reasons.

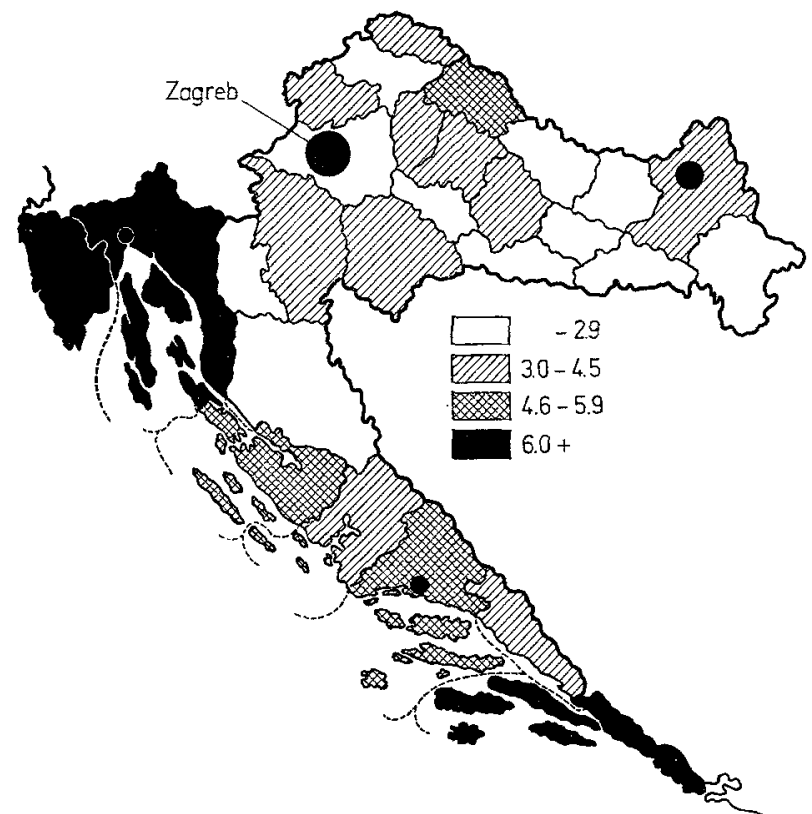

Fig. 2. Mortality from diabetes in Croatia per 100000 inhabitants. $1958-1962$

with active efforts to urge patients to apply for regular treatment, and the follow-up phase in the course of which the positives found in the screening phase are compared with "normal" matched pairs.

In the screening phase, the Hagedorn-Jensen method was used for the determination of blood sugar and the Benedict method for urine sugar. The critical 
value for positives was $160 \mathrm{mg}$ or more/100 $\mathrm{ml}$ of capillary blood sugar, or positive urine sugar.

In our investigation we chose the largest meal (dinner) as the screening load. The assumption was made that most diabetic disorders would be detected in the older people in whom 50 or $100 \mathrm{~g}$ glucose load is for the most part unusual and, perhaps, unphysiological.

The survey was so organized as to allow a number of parallel and controlled subsample analyses to be made. The biggest was a double blind experiment in the rural sampling unit, where both positives and an age-and-sex-matched control group of negatives were invited to an OGTT and a clinical examination. The group to which the invited persons belonged was known neither to them nor to the doctors.

\section{Results and Discussion}

The overall results are shown in Table 1. These results do not differ essentially from the results of a number of similar surveys $[17,9,16,8,2,3,15,18]$. They also show that, using an estimate based on extrapolation of actual results from a "low-prevalence survey" organized in the same way as ours, one can estimate results which are similar to those of a "highprevalence survey", where OGTT is used as a screening procedure [10].

Table 1. Overall results

\begin{tabular}{lrr}
\hline Screening positives & 505 & $(6.3 \%)$ \\
Refused further examination & 55 & $(\mathbf{1 1 . 4 \% )}$ \\
Known diabetics & 96 & $(1.1 \%)$ \\
Detected diabetics & 103 & $(1.3 \%)$ \\
Borderline cases & 224 & $(\mathbf{2 . 8 \% )}$ \\
Estimated proportion & & \\
of all OGTT positives & & $(\mathbf{1 2 . 1 \% )}$ \\
in the population examined & & \\
\hline
\end{tabular}

pirically on the basis of a number of criteria. We compared the percentage of the deceased in different diagnostic groups and in matched controls four years after examination (Table 2). A significant difference in the percentage of the deceased between newly detected diabetics and their controls was found. The impaired glucose tolerance can be estimated as a general health risk factor.

We followed the diabetics detected in the routine work of the health service in the observed region for four years after the survey (Table 3). The borderline group had a seven-fold risk even when correction for age was caloulated.

The frequency with which selected clinical findings were found in the various diagnostic groups is shown in Table 4. These results show that the differences between the group of known and that of newly de-

Table 2. Percentage of the Deceased in Groups of Patients and Matched Controls Four Years After Examination

\begin{tabular}{llcl}
\hline & \multicolumn{3}{l}{ Percentage of the deceased } \\
\cline { 2 - 4 } & Probands Controls & $\begin{array}{l}\text { Stat. signif. } \\
\text { of the } \\
\text { difference }\end{array}$ \\
\hline Known diabetics & 15.4 & 14.1 & NS \\
Detected diabetics & 17.2 & 9.6 & Significant \\
Borderline cases & 11.3 & 7.2 & NS \\
\hline
\end{tabular}

Table 3. Number of cases of diabetes diagnosed during four years after screening (urban areas)

\begin{tabular}{lccc}
\hline Population & & New Cases & $\%$ \\
\hline Borderline group & $\mathbf{1 7 5}$ & 8 & 4.57 \\
Screening negatives & $6 \mathbf{1 3 3}$ & 18 & 0.29 \\
$\quad$ Negatives 45 + yrs & 2368 & 18 & 0.76 \\
Now-comers in the & & & \\
$\quad$ area & $?$ & 6 & $\ldots$ \\
\hline
\end{tabular}

Table 4. Mean age and percentage (\%) of the examined with selected clinical findings

\begin{tabular}{lllllll}
\hline & $\begin{array}{l}\text { Mean } \\
\text { age }\end{array}$ & $\begin{array}{l}\text { Positive } \\
\text { family } \\
\text { history }\end{array}$ & Thirst & Polyuria & $\begin{array}{l}\text { Weight } \\
\text { lost }\end{array}$ & $\begin{array}{l}\text { Weight } \\
\text { (Broca) } \\
20.6+\mathrm{kg}\end{array}$ \\
\hline $\begin{array}{l}\text { Known } \\
\text { diabetics }\end{array}$ & 64.7 & 18 & 33 & 43 & 43 & 16 \\
$\begin{array}{l}\text { Detected } \\
\text { diabetics }\end{array}$ & 60.3 & 17 & 27 & 32 & 24 & 23 \\
$\begin{array}{l}\text { Borderline } \\
\text { Cases }\end{array}$ & 52.8 & 12 & 13 & 19 & 21 & 11 \\
$\begin{array}{l}\text { Screening } \\
\text { negatives }\end{array}$ & 41.2 & 7 & 12 & 12 & 10 & 10 \\
\hline
\end{tabular}

We analysed these results from three aspects: methodological, socio-medical and epidemiological.

\section{Corsideration of methods employed}

The basic problem of the methodological and tech. nical aspects of the survey is the assessment of the reliability and validity of the diagnostic procedure.

The validity of the procedure can be assessed em- tected diabetics were not statistically significant, but between those people screening negative and the group of detected diabetics significant differences were present.

However, all this relates only to groups, and the individual variability was great. Besides, age differences may partly account for the results obtained.

The problem of validity was examined more closely 
by our double blind experiment. The main task was to compare two screening procedures: a standard $50 \mathrm{~g}$ glucose load and a prandial load by a usual meal [5]. The ratio of actually positive results in the diagnostic phase to falsely negative results in the screening phase as obtained by both methods but with different critical values was 5:1 (Table 5). For this reason, accepting in the borderline region was nearly negligible. The relatively highest degree of reproducibility in retesting after 6 months was observed in oxyhyperglycaemic (lag-form) curves. They were often found in young men and were exhibited by $19.4 \%$ of all the persons examined in the diagnostic phase. However, it was not possible to prove a connection between this type of

Table 5. Comparison of matched pairs final diagnoses in a double blind experiment

\begin{tabular}{|c|c|c|c|c|}
\hline \multicolumn{2}{|c|}{$\begin{array}{l}\text { Sereening by } 50 \mathrm{~g} \text { of glueose, } \\
\text { critical value } 130 \mathrm{mg} \% \mathrm{BS} \\
\text { (25 pairs, } 12.7 \% \text { population) }\end{array}$} & & \multicolumn{2}{|c|}{$\begin{array}{l}\text { Screening by prandial load, } \\
\text { critical value } 160 \mathrm{mg} \% \text { BS } \\
\text { (47 pairs, } 5.9 \% \text { population) }\end{array}$} \\
\hline Probands & Controls & & Probands & Controls \\
\hline 47.0 & 45.3 & Mean age & 48.1 & 48.7 \\
\hline 203.3 & 210.3 & $\begin{array}{c}\text { Skinfold } \\
\text { (log.trans) }\end{array}$ & 210.0 & 202.2 \\
\hline $120^{\prime}$ & $120^{\prime}$ & $\begin{array}{l}\text { Screening } \\
\text { Time (BS-L) }\end{array}$ & $87.8^{\prime}$ & $83.7^{\prime}$ \\
\hline 153.4 & 94.3 & $\begin{array}{l}\text { Blood sugar } \\
\text { Diagnosis }\end{array}$ & 179.0 & 116.0 \\
\hline 5 & 1 & Diabetic & 10 & 2 \\
\hline 9 & 11 & Borderline & 22 & 19 \\
\hline 8 & 12 & Normal & 15 & 26 \\
\hline
\end{tabular}

that the diagnostic validity of the survey is proved, it remains necessary to validate the screening phase by building-in a control mechanism when the procedure is applied in any new condition.

In spite of the assumption that a prandial load can have not only technical but also theoretical advantages in defining practical health under more realistic conditions, we have seen that it is impossible to get a homogeneous composition of meals and reliable estimates of the time elapsing from eating to sampling. On the basis of this experience, we are of the opinion that for epidemiological comparison controlled glucose loading should be used.

Experience with the OGTT applied in the diagnostic phase enabled us to estimate reliability [7]. In borderline cases we repeated the OGTT at an interval of six months (Table 6). There was a higher relative speci-

Table 6. Correlation ( $r$ ) of blood sugar values in the repreated $100 \mathrm{~g} \mathrm{OGTT} \mathrm{(N} \mathrm{85,} \mathrm{"Borderline"} \mathrm{cases,} \mathrm{six} \mathrm{months} \mathrm{interval)}$

\begin{tabular}{llll}
\hline $\begin{array}{l}\text { Elements } \\
\text { of OGTT }\end{array}$ & $\begin{array}{l}\text { Correlation } \\
(r)\end{array}$ & $\begin{array}{l}\text { Corrected } \\
\text { correlation }\end{array}$ & $\begin{array}{l}\text { Prognostic } \\
\text { efficiency } \\
\text { index }\end{array}$ \\
\hline Easting (0) & 0.375 & 0.536 & 0.156 \\
60 min $(\mathrm{I})$ & 0.529 & 0.629 & 0.223 \\
120 min $(\mathrm{II})$ & 0.293 & 0.466 & $0.115<\Delta$. \\
& & & $P<.01$ \\
\hline $\mathrm{I}-0$ & 0.667 & 0.805 & 0.406 \\
$100 \times \mathrm{II} / \mathrm{I}$ & 0.414 & 0.392 & 0.079 \\
\hline$r_{\mathrm{I} / \mathrm{II}} 0.319$ & & &
\end{tabular}

ficity of the blood sugar determination 120 min after glucose loading, but a higher reliability of the blood sugar values $60 \mathrm{~min}$ after loading. On the whole, the reproducibility of the OGTT was low, so that the prognostic efficacy of a single examination for individuals curve and the occurrence of diabetes. It was because of these findings that the use of a blood sugar determination 60 min after the oral glucose loading showed comparatively a high reliability but a poor specificity for diabetes.

The results of the comparison of laboratory methods in our survey showed the great advantage of the enzymatic method for the detmination of urine glucose but not for that of blood glucose [12]. Both methods had practically the same variability coefficient: Hagedorn-Jensen $14.3 \%$, and glucose oxidase $17.4 \%$ (no significant difference). The hexose being present in diabetics in larger amounts may even increase the discriminatory power of a screening test.

It was shown that in a subsample the semi-quantitative determination of PAS-positive substances in the lymphocytes of the peripheral blood of fasting patients, correlated well $(0.7-0.8)$ with the blood sugar $120 \mathrm{~min}$ after loading. There was no statistically significant correlation between the fasting PAS indices and fasting blood sugar. The PAS index in the fasting state thus substantially predicts the results of the OGTT [13].

\section{Socio-medical aspects of the survey}

Although from the public health point of view the socio-medical results of a survey are very important, they are often neglected in the theory and presentation of data.

The response rate is an indicator of the population's co-operation, but new patients undergoing treatment are an indicator of the efficacy of the whole under. taking.

In our experience it was men and the better educated who refused most frequently to participate in the survey (Fig. 3). 
Fig. 4 shows the degree to which the proportion of those following instructions about diet and therapy in the final phase of the survey fell short of what we had hoped. In newly detected patients, the frequency of routine control examinations has been increased. The number of people restricting their sugar intake or following recommended medication was also reasonable. However, basic changes in diet, physical activity, and regular treatment in asymptomatic patients or borderline cases appear to have been achieved only with difficulty. The inquiry conducted by public health

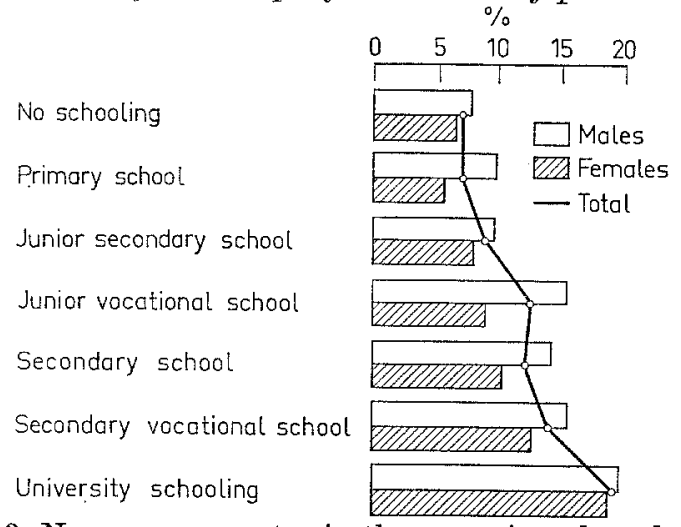

Fig. 3. Non-response rates in the screening phase by sex and schooling

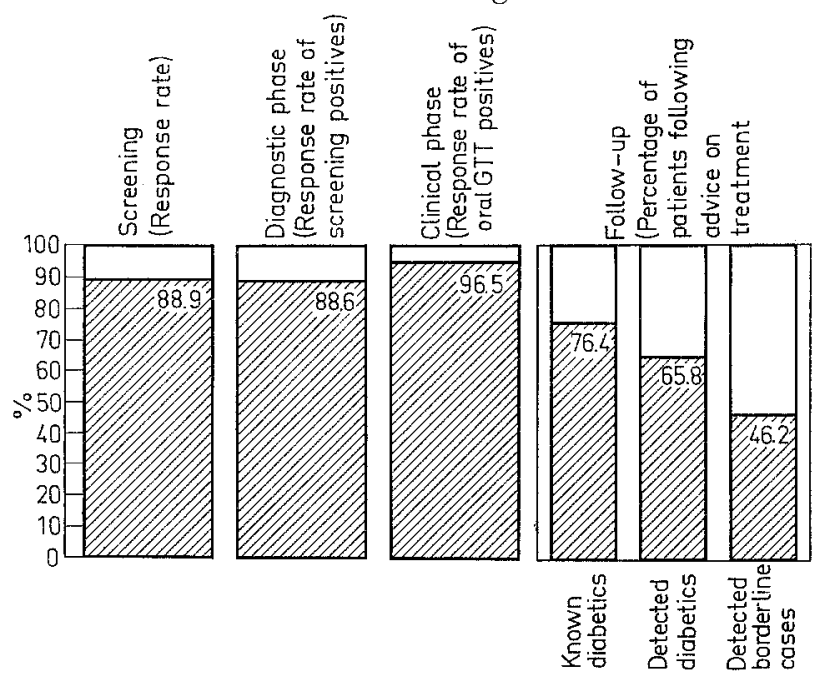

Fig. 4. Response rates in the Zagreb diabetes survey

nurses in the homes of the patients in the urban regions four years following the time of diagnosis, has shown that some of them have neglected treatment, in spite of the early diagnosis, individual and group recommendations and the free utilization of health services. In view of these results and the results of similar studies [11] of known diabetics, we have concluded that, from the point of view of public health, it is more important under present conditions to secure improvements in diagnostic and therapeutic activities in the regular health services as a first step, than to organize special mass examinations. Further operational and sociological research in this direction is needed.

\section{Epidemiological aspects of results}

A comparison of urban and rural areas shows that in our studies, the rural population (physically more active and less overweight) has had a significantly lower prevalence of diabetic findings in the adult and elderly groups (Fig. 5).

However, like others $[9,10]$, we have always obtained continuous positively-skewed, unimodal blood sugar distributions, both in the groups as a whole and in groups analysed by sex, age, body weight, and the time and kind of loading (Fig. 6).

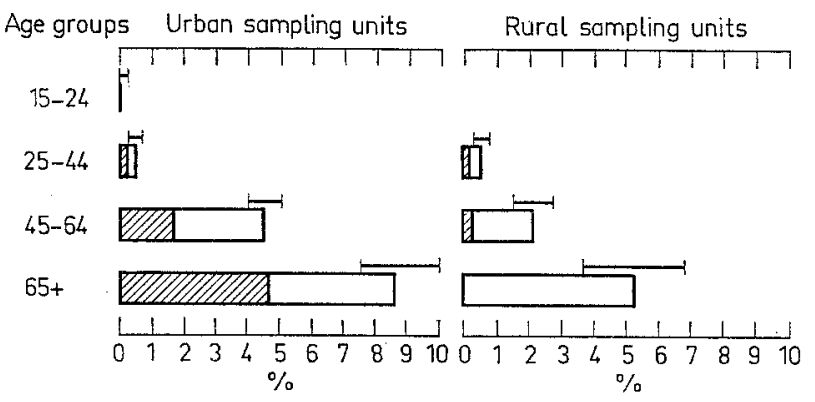

Fig. 5. Prevalence of known (IIIIII and detected $\square$ diabetics by age

$$
\begin{array}{ccc}
\text { Sex Age } & \begin{array}{l}
\text { Relative body Sampling time } \\
\text { weight (Broca) after loading }
\end{array} \\
\times \text {. Males } \times 15-24 \text { years } \times<(-3) \mathrm{kg} & \times 105-134 \mathrm{~min} \\
\text { - Females } 055-64 \text { years } & \circ>(+10) \mathrm{kg} & \circ 45-74 \mathrm{~min}
\end{array}
$$

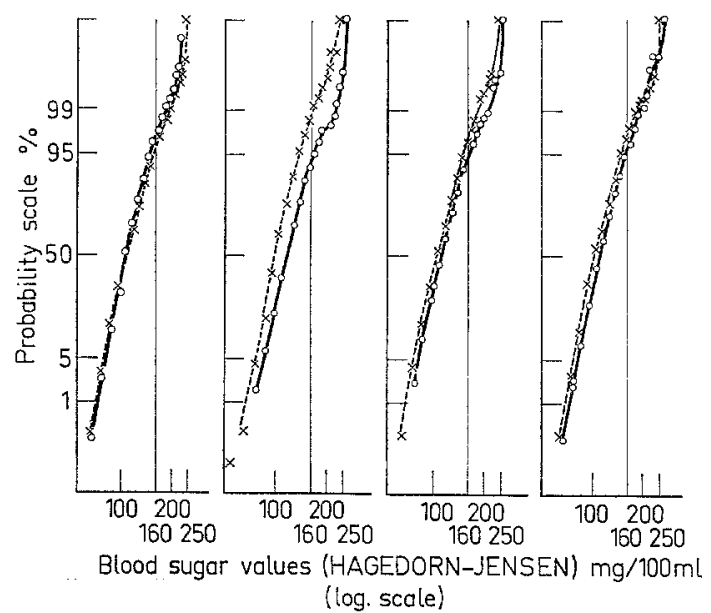

Fig. 6. Postprandial blood sugar distribution patterns

This indicates that in the use of common diagnostic methods for the diagnosis of diabetes in large population samples, it is necessary (a) to consider the final elinical diagnosis separately from biochemical findings, and (b) to regard as arbitrary any boundaries between healthy persons and diabetics drawn on the basis of a few blood sugar determinations.

For this reason we are of the opinion that the epidemiological observation of a "qualitative type" (by dividing the population into apparently healthy persons, borderlines and diabetics) is unjustifiable, and that the quantitative epidemiological analysis of blood sugar as a continuous variable (or "risk-factor") should 
be intensified, just as has been done for a long time in the epidemiology of the blood pressure or serum cholesterol $[7,4]$.

We have started work on the "quantitative analysis" by studying the correlation matrices of both parametric $(r)$ and nonparametric (Kendall's tau) correlations between selected epidemiological characteristics and blood sugar values (Table 7 ).
The relation between blood sugar values after prandial load and several other characteristics, such as age, relative body weight, interval between meals and blood sampling, positive family history, education (completed schooling), and occupation as an indicator of physical activity, was investigated. The multiple correlation coefficients $\left(R^{2}\right)$ both for parametric and nonparametric (Kendall's tau) correlations show, that

Table 7. Correlation matrix (Kendall's tau) of the postprandial blood sugar level and selected epidemiolagical characteristics (Urban areas)

\begin{tabular}{|c|c|c|c|c|c|c|}
\hline \multicolumn{7}{|c|}{ Males (N 1634) } \\
\hline $\mathrm{T}$ & A & W & $\mathrm{E}$ & PA & $\mathrm{F}$ & \\
\hline \multirow[t]{6}{*}{-0.135} & 0.187 & 0.062 & -0.024 & 0.136 & -0.001 & $\mathrm{~S}$ \\
\hline & 0.063 & 0.031 & -0.008 & 0.009 & 0.006 & $\mathrm{~T}$ \\
\hline & & $\underline{0.321}$ & -0.018 & 0.576 & -0.008 & A \\
\hline & & & -0.072 & $0 . \overline{172}$ & 0.032 & $W$ \\
\hline & & & & $0 . \overline{129}$ & 0.057 & $\mathrm{E}$ \\
\hline & & & & & -0.009 & PA \\
\hline \multicolumn{7}{|c|}{ Females (N 2032) } \\
\hline $\mathrm{T}$ & A & $W$ & $\mathbf{E}$ & PA & $\mathrm{F}$ & \\
\hline \multirow[t]{6}{*}{-0.069} & 0.198 & 0.105 & $-\overline{0.039}$ & 0.157 & 0.013 & $\mathrm{~S}$ \\
\hline & 0.075 & -0.009 & -0.055 & 0.067 & 0.031 & $\mathrm{~T}$ \\
\hline & & 0.377 & -0.156 & 0.561 & -0.025 & A \\
\hline & & & -0.201 & 0.338 & -0.003 & W \\
\hline & & & & 0.006 & 0.065 & $\mathrm{E}$ \\
\hline & & & & & 0.014 & PA \\
\hline
\end{tabular}

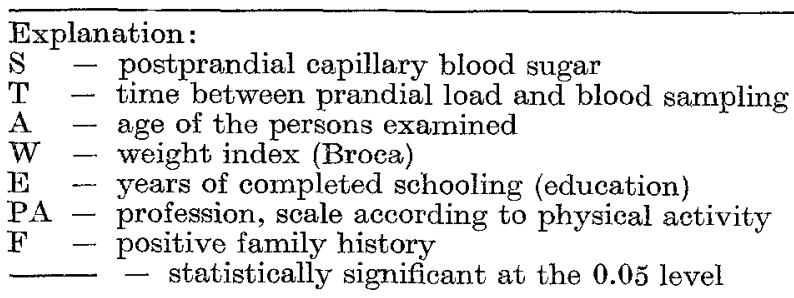

Table 8. Partial and multiple correlations of the postprandial blood sugar level and selected epidemiological characteristics (Urban areas)

\begin{tabular}{lrrr}
\hline & Males & Females \\
\hline S.F / T A W E P A & 0.002 & 0.015 \\
S.A / T W P A F & 0.198 & 0.204 \\
S.W / T A E P A F & 0.067 & 0.106 \\
S.E / T A W P A F & -0.025 & -0.043 \\
S.PA / T A W E F & 0.139 & 0.162 \\
PE / T A W E F & 0.014 & 0.012 \\
S.T / A W E P A F & -0.177 & -0.087 \\
\hline$R$ & 0.259 & 0.219 \\
$R^{2}$ & 0.067 & 0.048 \\
\hline
\end{tabular}

The analysis of these matrices, of which only extracts are presented, indicates that the positive family history of diabetes in our subjects is in fact only a function of the educational level. When this is taken into consideration, no evidence was obtained of correlation with blood sugar values. The correlation table also shows an interesting association between the relative body weight and completed schooling (education) in the persons examined: men show a positive and women a negative correlation. Better educated men are relatively fatter and women slimmer (Table 8). by observing and controlling these characteristics only $5-10 \%$ of the blood sugar variance could be explained (Table 9).

The total correlations are consistent but low. They are very similar to the parametric and nonparametric correlation coefficients.

Judging by the partial correlations observed, the strongest and most consistent relationship is that between blood sugar values and age, followed by the correlation between blood sugar values and the interval between meals and blood sampling.

The relative body weight, analysed by means of parametric correlations, does not show any significant partial correlation with blood sugar values. In view of this, it apears to us that the correlation between the degree of impaired glucose tolerance and relative increase in body weight, often reported from epidemiological surveys, could be only an epidemiological or methodological artefact, which may for the most part be explained by the population age structure. However, before accepting this conclusion two facts should be borne in mind: the type of loading preceding the blood sugar measurements (glucose or a large normal meal), and the fact that $88 \%$ or more of the ob- 
served population has by accepted criteria, no diminution of glucose tolerance. After loading with larger glucose doses $(100 \mathrm{~g})$, particularly in persons with a diminished glucose tolerance, the effect of body weight on the blood sugar may be seen far more clearly [7].
9. Kenny, A.J., A.L. Chute, and C.H. Best: A study of the prevalence of diabetes in an Ontario community. Canad. med. Ass. J. 65, 233-241 (1951).

10. O'Sullivan, J.B., and R.F. WilutaMs: Early diabetes mellitus in perspective. J. Amer. med. Ass. 198, $579-582(1966)$.

Table 9. Correlation (r) matrices, partial and multiple correlations of the postprandial blood sugar level and selected epidemiological characteristics (All sampling units)

\begin{tabular}{|c|c|c|c|c|c|c|c|c|}
\hline \multicolumn{4}{|c|}{ Males (N 2891) } & & \multicolumn{4}{|c|}{ Females (N 3596) } \\
\hline $\mathrm{T}$ & $A^{\prime}$ & $W$ & $\mathrm{E}$ & & & $A$ & W & $\mathrm{E}$ \\
\hline \multirow[t]{4}{*}{-0.128} & 0.239 & 0.107 & 0.062 & $\mathrm{~S}$ & -0.079 & 0.252 & 0.094 & -0.091 \\
\hline & 0.065 & 0.020 & 0.035 & $\mathrm{~T}$ & & 0.072 & $\overline{0.019}$ & -0.00 \\
\hline & & 0.337 & -0.042 & A & & & $\underline{0.419}$ & $=0.172$ \\
\hline & & & & & & & & $=0.237$ \\
\hline \multicolumn{2}{|c|}{ S.A / W TE } & 0.236 & & & \multicolumn{2}{|c|}{ S.A / W T E } & 0.247 & \\
\hline \multirow{2}{*}{\multicolumn{2}{|c|}{$\begin{array}{l}\text { S.W/A T E } \\
\text { S.T/A W E }\end{array}$}} & 0.037 & & & \multirow{2}{*}{\multicolumn{2}{|c|}{$\begin{array}{l}\text { S.W/A T E } \\
\text { S.T/A W E }\end{array}$}} & -0.024 & \\
\hline & & -0.153 & & & & & -0.102 & \\
\hline \multirow{2}{*}{\multicolumn{2}{|c|}{$\begin{array}{c}\mathrm{S} . \mathrm{E} / \mathrm{A} \mathrm{W} \mathrm{T} \\
R^{2}\end{array}$}} & 0.081 & & & \multicolumn{2}{|c|}{ S.E / A W T } & -0.053 & \\
\hline & & 0.085 & & & $R^{2}$ & & 0.074 & \\
\hline
\end{tabular}

Further analysis has shown that the estimation of physical activity by occupation is neither sensitive nor specific enough. When the effects of age and educational level were allowed for, no statistically significant residual correlation between blood sugar and occupation was evident.

Acknowledgments. The study was financed by the Research Fund of Croatia, Federal Research Fund, and Communal Bureau of Social Insurance in Zagreb. In mechanographic data processing, support was given by the Federal Institute of Public Health and the Pharmaceu. tical Works "Pliva".

\section{References}

1. Annual Epidemiological and Vital Statistics, 1959. Wld Hith Org. Genève, 1962.

2. Butrerfiel. W, W.J.H.: Summary of results of the Bedford Diabetes survey. Proc. roy. Soc. Med. 51, $196-200$ (1964).

3. Crombie, D. L.: Incidence of glycosuria and diabetes. Proc. roy. Soc. Med. 55, 205-207 (1962).

4. Epstein, F.H., T. Francts, Jr., N.S. Hayner, B.C. Johnson, M.O. KJElsberg, J.A. NAPIER, L.D. Ostrander, Jr., M. W. PAYNE, and H.J. DODGE: Prevalence of chronic diseases and distribution of selected physiologic variables in a total community, Tecumseh, Michigan. Amer. J. Epidem. 81, 307-322 (1965).

5. JAKŠIĆ, Z̆.: Dvostruko slijepi pokus unutar akcije ranog otkrivanja šećerne bolsti (Double blind trial within the diabetes detection survey). Admission Work for the Venia Legendi at the Zagreb Medical Faculty. Zagreb, 1967.

6. - Sećerna bolest na podruěju SR Hrvatske prema podacima vitalne i zdravstvene statistike (Diabetes mellitus in Croatia according to vital and health statistics). Zdrav. novine 18, 95-114 (1965).

7. - Ocjena proširenosti šećerne bolesti i njeno rano otkrivanje (Assessment of the prevalence of diabetes and its early detection). Doctor of Science Degree Thesis. Zagreb, 1965.

8. JORde, R.: The diabetes survey in Bergen, Norway, 1956. Bergen-Oslo, 1963.
11. SAớer, Lj., and Ž. JAKŠró: Socijalno-medicinski problemi koji utječu na praktično provodjenje liječenja dijabetičkih bolesnika (Survey of socio-medical problems influencing the treatment of diabetics). Zdrav. novine 18, 154-163 (1965).

12. Škrabalo, Z., N. Dmmtrov, B. Hruš, Ž. Jakš̀ć, and M. Todorovió: Enzimatske metode odredjivanja šećera u krvi i mokraći (Methodes enzymatiques de la determination du sucre dans le sang et l'urine). Medicinski Pregl. 17, 357-362 (1965).

13. - A. StravlJenIó, T. C̆ RePINKo, and Z̆. JAKŠIó: PASpozitivne supstancije u limfocitima periferne $\mathrm{krvi}$ zdravih ljudi, dijabetičara i tzv. graničnih slučajeva dijabetesa (PAS-positive substances in peripheral blood lymphocytes in healthy persons, in diabeties, and in borderline cases of diabetes). The First Yugoslav Symposium on Diabetes, Zagreb 1967, p. 276. Zagreb, 1968.

14. Somliack, V.: Reihenuntersuchungen zur Erkennung von Diabetikern. III Kongress der International Diabetes Federation, Düsseldorf 1958. Stuttgart, 1959.

15. - Diabetes-Suchaktionen in Europa. The First Yugoslav Symposium on Diabetes, Zagreb 1967, p. 120. Zagreb, 1968.

16. WALKER, J.B., and D. KerRIDGE: Diabetes in an English Community. Leicester, 1961.

17. Wrukerson, H.L.C., and L.P. Krall: Diabetes in a Now England town: A study of 3,516 persons in Oxford, Massachusetts. J. Amer. med. Ass. 135, 209216 (1947)

18. Wld. Hlth. Org. techn. Rep. Ser. 310 (1965).

Dr. ŽELIMIR JAKŠIĆ

Andrija Štampar School of Public Health

Medical Faculty, University of Zagreb

Rockefellerova 4

Zagreb/Yugoslavia

Dr. ZDENKo ŠKRABALO

Vuk Vrhovac Centre for Diabetes

Department of Medicine within the

Ozren Novosel Hospital

Medical Faculty, University of Zagreb

Petrinjska 34

Zagreb/Yugoslavia 